\title{
GOVERNANCE DAN KOLOM AGAMA PADA ADMINISTRASI KEPENDUDUKAN
}

\author{
Sughron Jazila \\ STISIP Setia Budhi Rangkasbitung, Lebak, Banten \\ azil.sughronjazila@gmail.com
}

\begin{abstract}
Abstrak. Di Indonesia, agama merupakan sebuah objek yang hidup di dalam ruang lingkup negara, bahkan warga negara harus mengisi kolom agama pada saat proses administrasi kependudukan seperti KTP dan/atau KK dan memilih agama yang diakui pemerintah. Padahal ada juga kaum beragama lain yang memang bukan disebut agama, tetapi kepercayaan. Maka di dalam konsep governance ini menjadi masalah ketika ada kelompok yang juga terdampak oleh kebijakan pengisian kolom agama pada administrasi kependudukan tetapi tidak diikutsertakan pada kebijakan. Metode yang digunakan pada penelitian ini adalah studi kualitatif-deskriptif yang menggambarkan problem governance yang terjadi pada para penghayat kepercayaan dan dampak yang muncul pada para penghayat kepercayaan. Temuan studi ini ialah bahwa terjadi pemaksaan dari negara kepada para penghayat kepercayaan ketika ada kolom agama pada dokumen administrasi kependudukan, dan meningkatkan potensi ancaman konflik yang terjadi di Indonesia.
\end{abstract}

Kata Kunci: Governance, KTP, Agama, Kepercayaan

\section{PENDAHULUAN}

Di dalam ranah administrasi publik, ada paradigma-paradigma yang mewarnai. Paradigma-paradigma tersebut disesuaikan dengan kondisi sosial serta perkembangan apa yang terjadi pada masa itu. Maka paradigma dalam administrasi publik selalu berkembang, bergeser, dan berubah dari waktu ke waktu. Mulai dari Old Public Administration (OPA) yang direduksi dari pemikiran Woodrow Wilson yang memisahkan politik dan administrasi, yang bergeser menjadi New Public Management (NPM) yang berdasarkan pada tata kelola yang ada pada perusahaan/sektor privat. Kemudian muncul lagi sebuah paradigma baru yang disesuaikan dengan perkembangan saat ini, di mana ada beberapa ahli yang mencoba merumuskan paradigma baru tersebut, seperti Seperti Janet dan Robert Denhadts (2007) dengan bukunya New
Public Service. Atau Gerry Stoker (2006) yang menulis Public Value Management, Barry Bozeman (2007) menulis Managing Publicness, Stephen Osborne (2010) menulis Public Governance dan ahli teori politik Harry Boyte yang menulis New Civic Politics. Berbagai pendapat para ahli tersebut terdiri dari pendekatan yang berbedabeda. Tetapi yang harus diperhatikan bahwa setiap ahli menekankan pentingnya value atau nilai dalam setiap pelayanan kepada publik yang dilakukan oleh negara.

Dalam pendekatan baru paradigma administrasi publik, ada empat hal yang menjadi perhatian utama. Pertama adalah penekanan pada public value; kedua adalah dorongan agar pemerintah bertugas menjadi penjamin utama berdirinya public value; ketiga adalah dorongan agar masyarakat sadar pentingnya manajemen publik (public management); dan keempat adalah 
pelayanan dari dan untuk publik. Paradigma baru tersebut sangat terpengaruh dari konsep demokrasi, di mana menuntut keterlibatan berbagai pihak-pihak terkait untuk menciptakan sebuah kebijakan yang membahas isuisu strategis dalam negara.

Sejalan dengan perkembangan paradigma tersebut, maka dikenalkan pula governance, sebuah konsep tata kelola pemerintahan yang bertujuan untuk pemerintahan bertujuan untuk menjaring keterlibatan dari berbagai pihak yang memiliki pengetahuan dan yang terkena dampak dari kebijakan (Benz \& Papadopoulos : 2006) yang akan dilakukan dan / atau yang sedang dilakukan. Maka bisa disebut pula bahwa governance adalah sebuah interaksi antara pemerintah dengan pihak-pihak terkait dalam pembuatan dan pelaksanaan kebijakan seperti para administrator, anggota dewan, dan juga para ahli yang dianggap mengerti, serta aktor-aktor yang terlibat dalam proses politik, seperti para politisi, media massa, dan juga para spin doctors (Benz \& Papadopoulos : 2006). Maka secara umum governance diartikan sebagai bagaimana pemerintah melibatkan dan berhubungan dengan masyarakat yang menjadi objek kebijakan, para pengusaha sektor privat, politisi, NGO, para ahli, dan pihak-pihak yang memang terdampak dari kebijakan tersebut. Oleh karena itu maka lahirlah konsep good governance yang bertujuan untuk melibatkan para stakeholders dalam proses pembuatan serta pelaksanaan kebijakan dalam berbagai bidang, mulai dari bidang ekonomi, sosial, politik, sumber daya alam, pendidikan, dan lainnya yang memang untuk kepentingan masyarakat dengan menganut asas keadilan, persamaan, perataan, akuntabel, dan efisien (World
Conference on Governance, UNDP, 1999 dalam Sedarmayanti : 2007).

Good governance sendiri adalah cara kekuasaan negara digunakan dalam mengelola sumber daya ekonomi dan sosial untuk pengembangan masyarakat (World Bank). Ada beberapa prinsip good governance yang dituangkan oleh UNDP (1997), antara lain:
a) Partisipasi;
b) Rule of law,
c) Transparansi;
d) Responsif;
e) Berorientasi konsensus;
f) Adil;
g) Efektif dan efisien;
h) Akuntabel; dan
i) Visi strategis.

\section{PROBLEM GOVERNANCE}

Dengan munculnya konsep good governance, membuat pemerintah harus bersikap demokratis dan melibatkan para pihak yang memang mengerti dan terdampak dari kebijakan tersebut. Maka, disini muncul beberapa permasalahan. Ada 5 permasalahan terkait dengan governance jika dikaitkan dengan demokrasi (Benz \& Papadopoulos : 2006), yaitu:

1. Kelompok mana yang akan dimasukkan di dalam struktural pengambilan keputusan, siapa yang akan memutuskan inklusi dan kriteria dari inklusi tersebut (misalnya, wilayah teritorial, atau fungsional suatu kelompok dan beberapa kelompok lain), dan sejauh mana struktur tersebut akan dibuka 
untuk sewaktu-waktu memasukkan aktor baru?

2. Pertimbangan apa yang memberi legitimasi dari aktor-aktor tersebut untuk membuat keputusan?

3. Di manakah posisi alternatif kebijakan yang dihasilkan oleh keputusan kolektif berbagai aktor tersebut akan terbentuk? Apakah proses pembuatannya memang menjamin adanya masukan dari konstituen?

4. Bagaimana dengan para administrator dalam pemerintahan terkait dengan alternatif kebijakan yang didasari dari konstituen mereka sendiri? Apa yang bisa dilakukan oleh para konstituen untuk memeriksa kebijakan dari para administrator dan menjadikannya efektif serta bertanggung jawab terhadap hasil pembuatan kebijakan pemerintahan?

5. Bagaimana sebuah alternatif bisa dijadikan sebuah keputusan di dalam pemerintahan? Sejauh mana sebuah kebijakan memungkinkan untuk mengubah preferensi kelompok yang terkena dampak?

Kemudian penjelasan lebih lanjut dari Benz \& Papadopoulos adalah sebagai berikut:

Pertanyaan pertama, governance juga mencakup kelompok dengan memberi wakil mereka akses ke dalam proses pembuatan kebijakan. Namun, cakupannya cenderung tidak hanya elitis tetapi juga selektif berkenaan dengan pertimbangan kepentingan, karena tidak semua konstituen memiliki potensi yang sama untuk memaksakan perwakilannya dalam pembuatan kebijakan. Meski diakui tingkat pluralisme bervariasi, governance jarang melibatkan kepentingan yang lemah secara organisasi. Selain itu, semakin banyak itu pembuatan kebijakan mengkonsolidasikan jaringan, potensi kolusi antar mereka akan semakin besar dan pembentukan koalisi distributif cenderung merangsang terjadinya rent-seeking, kecenderungan partikularisme, dan kecenderungan akan ada pembiayaan baru yang dibebankan. Kebutuhan fungsional untuk kohesi jaringan internal dapat menyebabkan prasangka terhadap respon eksternal. Juga yang perlu diperhatikan adalah bahwa legitimasi mekanisme dari governance terutama bergantung pada kepatuhan para aktor yang memiliki potensi tinggi melakukan blackmailing, dan mampu memveto formulasi kebijakan atau implementasi. Akibatnya, dorongan terkuat berasal dari pihak yang bisa memveto tersebut, yang segala tindakannya berpotensi membahayakan public action atau policy choices.

Pertanyaan kedua, ciri khas dari governance adalah penggabungan berbagai kelompok kepentingan dalam pengambilan keputusan (kepentingan pribadi pihak pemerintah adalah hal yang paling menonjol). Mereka biasanya disambut sebagai indikator politik yang lebih horisontal dan plural. Selain itu, upaya untuk mempertimbangkan pengetahuan para ahli dihargai sebagai ciri-ciri pembuatan kebijakan yang lebih reflektif. Namun 
analisis tentang governance tidak banyak bicara tentang hubungan antara governance dan lingkaran demokratis. Tidak hanya aturan permainan dan tujuan dari governance dan demokratis tersebut berbeda, tetapi aktor-aktor yang terlibat dalam arena governance (administrator, representatif kelompok kepentingan, dan para ahli) sangat berbeda dari sekelompok aktor yang mengintervensi arena politik (politisi, editor jurnal dan spin-doctor). Akibatnya muncul resiko bahwa keputusan dibuat oleh aktor selain yang dianggap sebagai pengambil keputusan yang sah oleh rakyat atau kelompok yang terkena dampak kebijakan.

Pertanyaan ketiga, dalam governance, preferensi kebijakan diperkenalkan ke dalam proses politik oleh collective actors dari berbagai aktor yang berbeda kepada para konstituen. Beberapa dari mereka (konstituen) memutuskan preferensi mereka lewat proses pemberian suara kepada mereka yang mewakili para konstituen. Yang lain memberdayakan seorang elit untuk membuat keputusan, dan yang diwakili dapat bereaksi hanya dengan meninggalkan organisasi (keluar) jika mereka menganggap tuntutannya belum dipenuhi. Pada pandangan pertama, tampaknya proses demokrasi pembentukan preferensi dalam collective actors yang diwakili dalam struktur governance berkontribusi pada kualitas demokrasi pemerintahan. Namun, aktor kolektif non-demokratis yang berbicara dengan satu suara sering dapat diamati mengartikulasikan kepentingan mereka secara lebih efektif daripada perwakilan kelompok kepentingan yang harus berpegang pada kehendak konstituensi mereka. Para pemimpin organisasi yang otonom dapat bereaksi lebih baik terhadap perkembangan proses negosiasi yang biasanya tidak dapat diprediksi yang menjaid tipikal governance daripada pemimpin organisasi yang demokratis. Yang terakhir harus mengatasi kesenjangan antara 'logic of influence' yang menjiwai mereka dan 'logic of membership' yang menjiwai kelompok mereka.

Pertanyaan keempat, masalah kurangnya inklusifitas dan pertimbangan kepentingan yang tidak cukup memadai dalam governance sangat terkait dengan masalah daya tanggap dan akuntabilitas. Beberapa aktor yang mengambil bagian dalam policy networks tidak selalu pemegang mandat rakyat, mereka tidak dibatasi oleh janji pemilu, dan mereka tidak harus mengantisipasi sanksi pemilu. Ketika mereka memiliki pertimbanganpertimbangan ini, misalnya sebagai perwakilan kelompok kepentingan, maka mereka bertanggung jawab kepada kepentingan sektoral dan tidak untuk banyak kepentingan. Selain itu, persyaratan tradisional delegasi yang seharusnya mewakili kepentingan kelompoknya dirusak oleh pemberian peran sentral untuk tawar-menawar atau musyawarah: para pelaku yang terlibat kemudian lebih sering bertanggung jawab kepada mitra diskusi mereka dalam musyarawah daripada kelompok yang dia wakili. Akhirnya, ketidakstabilan dan informalitas yang sering terjadi, atau setidaknya tingkat konsolidasi yang lemah, prosedur governance cenderung membuat pembuatan kebijakan kurang terlihat oleh warga biasa. Kepercayaan pada keadilan prosedural dapat meningkatkan penerimaan keputusan, dan keyakinan ini juga bergantung pada keyakinan bahwa, berapapun biaya yang mungkin berasal dari keputusan itu, itu diambil dalam kondisi yang dapat diperkirakan adil. Dalam hal itu, policy networks 
lebih mudah dikritik sebagai kurangnya keadilan daripada para mayoritas anggota parlemen, yang dapat lebih mudah tampak sebagai ekspresi 'alami' dari kehendak rakyat, meskipun terkadang 'diproduksi' oleh undangundang pemilu. Karena kekuatan ideologi demokrasi, pertimbangan transparansi dan akses yang sama terhadap musyawarah sangat mungkin berlaku dalam penilaian prosedur putusan, sehingga memberikan legitimasi mekanisme governance yang bermasalah.

Pertanyaan kelima, pembuatan kebijakan oleh governance dapat dianggap lebih kondusif untuk pemerintahan yang efektif. Misalnya, telah diperdebatkan bahwa negosiasi dalam networks, jika mereka cukup plural, akan mampu menghasilkan hasil yang optimal. Dengan asumsi bahwa persepsi umum yang berlaku lebih mengandalkan pertimbangan kepentingan sesuai kesepakatan konsensus governance daripada pertimbangan identitas, legitimasi sistem politik akan terutama dicapai melalui kinerja governance yang efisien. Studi empiris juga menunjukkan bahwa mekanisme governance dapat menghasilkan output yang lebih menguntungkan bagi kelompok-kelompok yang distigmatisasi secara sosial daripada mekanisme perwakilan atau partisipatif di mana godaan untuk demagoginya tinggi. Governance mungkin juga lebih baik terhadap 'ketahanan', dan menghasilkan lebih banyak keputusan 'terkait masa depan', karena para pembuat keputusan tidak dibatasi oleh perhitungan jangka pendek persaingan pemilu. Akhirnya, para aktor dalam networks seperti para pakar dan perwakilan kepentingan dianggap sangat kompeten dalam mengumpulkan pengetahuan teknis, sektoral dan lokal yang diperlukan untuk menghasilkan output yang memadai. Singkatnya, governance akan menguntungkan 'fakta-, masa depan-, dan hal-hal lainnya'

Maka sesuai dengan latar belakang tersebut, penulisan artikel ini akan cenderung membahas konsep permasalahan governance yang disebutkan oleh Benz dan Papadopoulos. Pembahasan problem-problem tersebut akan dikaitkan dengan fenomena kolom agama pada Administrasi Kependudukan (KTP dan KK). Nantinya fenomena ini juga akan disilangkan dengan nilai-nilai Pancasila.

\section{KOLOM AGAMA PADA ADMINISTRASI KEPENDUDUKAN}

Negara adalah sebuah organisasi raksasa yang berfungsi untuk penertiban, kesejahteraan dan kemakmuran rakyat, pertahanan, dan juga untuk keadilan (Miriam Budiardjo). Maka otomatis rakyat mendapatkan perlindungan dari pemerintah dalam hal apapun, termasuk kepastian dari status pribadi yang harus tertulis dalam hukum negara, karena ini merupakan hak dari setiap warga negara. Perlindungan status warga negara di mata negara diawali dari munculnya Undang-Undang Nomor 23 Tahun 2006 Tentang Administrasi Kependudukan yang kemudian diperbaharui lagi dengan Undang-Undang Nomor 24 Tahun 2013 serta Peraturan Pelaksanaannya, yaitu Peraturan Pemerintah Nomor 37 Tahun 2007. Maka setiap warga negara di Indonesia diwajibkan untuk memiliki Kartu Keluarga (KK) dan juga Kartu Tanda Penduduk (KTP).

Kemudian pada Pasal 61 ayat (1) Undang-Undang Administrasi Kependudukan mengatur tentang 
informasi apa saja yang tertulis di dalam KK, yaitu kolom nomor KK, nama lengkap kepala keluarga \& anggota keluarga, NIK, jenis kelamin, alamat, tempat lahir, tanggal lahir, agama, pendidikan, pekerjaan, status perkawinan, status hubungan dalam keluarga, kewarganegaraan, dokumen imigrasi, dan nama orang tua. Sedangkan pada Pasal 61 ayat (2) menyatakan bahwa penduduk yang agamanya belum diakui peraturan perundangan atau penghayat kepercayaan, maka informasi agama di dalam KK tidak perlu diisi.

Adapula Pasal 64 ayat (1) yang mengatur tentang informasi yang harus tercantum dalam KTP, yaitu gambar lambang Garuda Pancasila dan peta wilayah negara Republik Indonesia, memuat keterangan tentang NIK, nama, tempat tanggal lahir, laki-laki atau perempuan, agama, status perkawinan, golongan darah, alamat, pekerjaan, kewarganegaraan, pas foto, masa berlaku, tempat dan tanggal dikeluarkan KTP, tandatangan pemegang KTP, serta memuat nama dan nomor induk pegawai pejabat yang menandatanganinya. Sama seperti KK, pada UU Administrasi Kependudukan Pasal 64 ayat (2) juga mengharuskan pengosongan kolom agama bagi para penganut agama yang belum diakui perundangan atau penghayat kepercayaan. Kolom agama yang dikosongkan pada KTP dan KK tersebut dikosongkan dan/atau diberi tanda (-).

Yang menjadi permasalahan selanjutnya adalah bahwa negara hanya mengakui 6 agama resmi, yaitu Islam, Kristen, Katolik, Hindu, dan Budha, padahal ada juga aliran penganut atau penghayat kepercayaan

\footnotetext{
1 https://nasional.tempo.co/read/1031968/ceritapenganut-aliran-kepercayaan-yang-harusmenyamar-di-ktp
}

yang juga telah lama ada di Indonesia. Bahkan sebelum ke-6 agama besar tersebut datang ke Indonesia, sudah ada masyarakat nusantara yang menganut penghayat kepercayaan (Pelly : 2000). Ini membuat para penganut kepercayaan, sebelum munculnya UU No. 23 Tahun 2006, terpaksa untuk berpura-pura menjadi penganut agama-agama mayoritas yang diakui oleh pemerintah Republik Indonesia ${ }^{1}$. Kolom agama pada identitas resmi mereka seperti KTP dan KK pun menjadi tercantum agama mayoritas, walaupun mereka tidak meyakininya.

Memang, jumlah penganut kepercayaan di Indonesia belum pasti. Berdasarkan data Sensus Penduduk Tahun 2010 (SP2010)², jumlah para penghayat kepercayaan di Indonesia bisa dikatakan kecil. Tercatat ada 299.617 orang yang menjadi penghayat kepercayaan yang ditulis sebagai kelompok "lainnya" dalam sensus tersebut, atau sekitar 0,13\% dari total penduduk yang ada di Indonesia. Kelompok "lainnya" tersebut adalah kelompok yang memberi jawaban selain ke enam agama resmi yang diakui oleh negara (lihat tabel 1). Tetapi perlu diingat, bahwa ada kemungkinan para penghayat kepercayaan mendaftarkan dirinya sebagai salah satu umat dari agama yang resmi.

\section{Tabel 1}

Agama yang Dianut Masyarakat Indonesia

\begin{tabular}{|l|r|}
\hline \multicolumn{1}{|c|}{ AGAMA } & \multicolumn{1}{c|}{ JUMLAH } \\
\hline Islam & 207.176 .162 \\
\hline Kristen & 16.528 .513 \\
\hline Katolik & 6.907 .873 \\
\hline Hindu & 4.012 .116 \\
\hline Budha & 1.703 .254 \\
\hline
\end{tabular}

https://sp2010.bps.go.id/index.php/site/tabel?tid $=321 \&$ wid $=0$ 


\begin{tabular}{|l|r|}
\hline $\begin{array}{l}\text { Khong Hu } \\
\text { Chu }\end{array}$ & 117.091 \\
\hline Lainnya & 299.617 \\
\hline $\begin{array}{l}\text { Tidak } \\
\text { Terjawab }\end{array}$ & 139.582 \\
\hline $\begin{array}{l}\text { Tidak } \\
\text { Ditanyakan }\end{array}$ & 757.118 \\
\hline
\end{tabular}

Sumber: diolah penulis dari BPS SP2010

Ketidak validan tersebut juga terlihat dari data yang dirilis oleh Kementerian Pendidikan dan Kebudayaan (Kemendikbud) yang mencatat bahwa ada 12 juta orang penghayat kepercayaan dan ada 187 organisasi penghayat kepercayaan di Indonesia yang tercatat oleh Kemendikbud yang tersebar dalam 13 provinsi (lihat tabel 2).

\section{Tabel 2}

Daftar Persebaran

Kelompok Penghayat Kepercayaan

\begin{tabular}{|l|r|}
\hline \multicolumn{1}{|c|}{ PROVINSI } & JUMLAH \\
\hline Sumatera Utara & 12 \\
& kelompok \\
\hline Riau & 1 kelompok \\
\hline Lampung & 5 kelompok \\
\hline Banten & 1 kelompok \\
\hline DKI Jakarta & 14 \\
& kelompok \\
\hline Jawa Barat & 7 kelompok \\
\hline Jawa Tengah & 53 \\
& kelompok \\
\hline DI Yogjakarta & 25 \\
& kelompok \\
\hline Jaya Timur & 50 \\
& kelompok \\
\hline Bali & 8 kelompok \\
\hline Nusa Tenggara Barat & 2 kelompok \\
\hline Nusa Tenggara Timur & 5 kelompok \\
\hline Sulawesi Utara & 4 kelompok \\
\hline
\end{tabular}

3 https://nasional.kompas.com/read/2017/11/09/1
Sumber: Direktorat Pembinaan Kepercayaan Terhadap Tuhan YME dan Tradisi Kemendikbud ${ }^{3}$

Data Kemendikbud ini belum tersinkronisasi dengan data yang dimiliki Kemendagri maupun Kemenag. Tetapi yang harus diingat adalah bahwa berapapun jumlah para penganut penghayat kepercayaan yang ada, fakta bahwa banyak masyarakat penganut aliran kepercayaan yang terpaksa menulis kolom agama pada dokumen administrasi kependudukan menunjukkan bahwa negara memaksakan kehendak kepada warga negara pada ruang-ruang yang seharusnya berada pada ruang privat, yang juga ruang privat ini diamanatkan dan dijamin oleh Undang-Undang Dasar 1945 Pasal 29 ayat 2 yang berbunyi "Negara menjamin kemerdekaan tiap-tiap penduduk untuk memeluk agamanya masing-masing dan untuk beribadat menurut agamanya dan kepercayaannya itu".

Pemaksaan-pemaksaan tersebut akan menjadi api dalam sekam dan akhirnya akan menimbulkan konflik. Konflik adalah ekspresi heterogenitas kepentingan, nilai, dan keyakinan yang muncul sebagai formasi baru yang ditimbulkan oleh perubahan sosial yang muncul bertentangan dengan hambatan yang diwariskan (Miall : 2000). Maka ketika pertemuan antar kepentingan kolom agama tersebut muncul, akan terjadi konflik jika tidak segera diantisipasi. Apalagi interaksi antar pemeluk agama sering terjadi di Indonesia, baik antara pemeluk agama yang sama dan juga hubungan umat antar agama. Maka ketika muncul diskriminasi dan permasalahan pada kolom agama pada dokumen 
administrasi kependudukan, agama rawan menjadi sumber ketidakadilan dan juga sumber konflik karena identitas dalam administrasi kependudukan tersebut membuat seseorang menjadi terlabeli dengan mayoritas atau minoritas secara tidak langsung. ini jelas menjadi tantangan sekaligus kesulitan bagi pemerintah dalam memasukkan indikator agama di dalam dokumen resmi warga negara.

\section{METODE PENELITIAN}

Studi ini menggunakan pendekatan kualitatif deskriptif yang menggambarkan dan memperjelas pentingnya pemerintah untuk memperhatikan hak-hak warga negara, dalam hal ini para penghayat kepercayaan di dalam administrasi kependudukan, karena ini berkaitan juga dengan governance yang terjadi di Indonesia. Penelitian kualitatif digunakan di dalam penelitian ini karena sifat penelitian ini yang memahami fenomena kolom agama melalui gambaran holistik dan tarikan pada nilai dan konteks para pelaku pemerintahan dan warga negara. Sumber data yang digunakan merupakan data sekunder, termasuk mengutip sebagian hasil riset yang telah dilakukan sebelumnya dan juga data dari media massa sebagai bahan pelengkap.

\section{HASIL DAN PEMBAHASAN}

\section{Problem Governance dalam Kolom Agama Pada Administrasi Kependudukan}

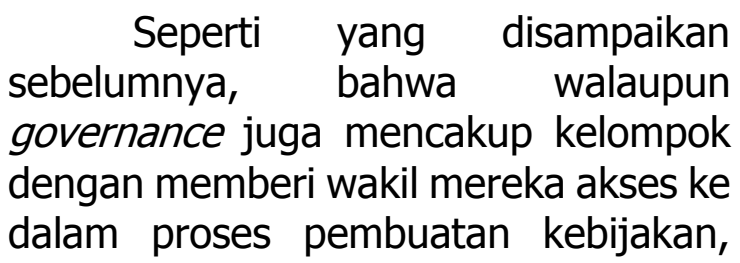

tetapi cakupannya cenderung tidak hanya elitis tetapi juga selektif berkenaan dengan pertimbangan kepentingan, karena tidak semua konstituen memiliki potensi yang sama untuk memaksakan perwakilannya dalam pembuatan kebijakan.

Berkaitan dengan kolom agama pada KTP, maka berbicara juga tentang agama. Agama sendiri hakikatnya adalah sebuah pembicaraan tentang interpretasi agama, dan faktanya memang tidak ada interpretasi tunggal dalam agama ataupun kepercayaan apapun. Faktanya, setiap pemeluk agama apapun dan kepercayaan apapun pasti berkata bahwa agama yang diyakininya adalah sebuah kebenaran, dan melakukan penalaran dan penjabaran dan juga berargumen untuk memaparkan bukti-bukti dan fenomena yang ada untuk membuktikan interpretasinya tersebut. Maka ketika hal itu terjadi, keberagaman agama dan kepercayaan adalah sebuah hal dan keniscayaan yang pasti terjadi.

Yang menjadi permasalahan adalah ketika negara memaksa interpretasi agama pada pemutlakan agama menjadi 6 agama saja, maka negara telah merongrong hak dari masyarakat, terutama para penganut kepercayaan. Dikaitkan dengan kerangka problem governance milik Benz dan Papadopoulos, walaupun jelas harus ada pluralisme di dalam urusan kolom agama pada administrasi kependudukan, governance jarang melibatkan kepentingan yang lemah secara organisasi. Faktanya, struktur organisasi dari kelompok penghayat kepercayaan memang lemah. Dari 187 organisasi penghayat kepercayaan di Indonesia yang terdata di Kemendikbud, ada 27 organisasi yang tidak aktif. 
Tabel 3

Jumlah Organisasi

Penghayat Kepercayaan yang

Tidak Aktif

\begin{tabular}{|l|c|}
\multicolumn{1}{c|}{ PROVINSI } & JUMLAH \\
\hline Sumatera Utara & 1 kelompok \\
\hline Riau & - \\
\hline Lampung & - \\
\hline Banten & 1 kelompok \\
\hline DKI Jakarta & 2 kelompok \\
\hline Jawa Barat & 2 kelompok \\
\hline Jawa Tengah & 5 kelompok \\
\hline DI Yogjakarta & 5 kelompok \\
\hline Jaya Timur & 7 kelompok \\
\hline Bali & - \\
\hline Nusa Tenggara Barat & 1 kelompok \\
\hline Nusa Tenggara Timur & 1 kelompok \\
\hline Sulawesi Utara & 1 kelompok \\
\hline
\end{tabular}

Sumber: Direktorat Pembinaan

Kepercayaan Terhadap Tuhan YME

dan Tradisi Kemendikbud ${ }^{4}$

Dari data tersebut terlihat bahwa organisasi para penghayat kepercayaan tersebut bersifat dinamis. Ada saatnya ketika organisasi penghayat kepercayaan menjadi tidak aktif, atau malah bisa saja tidak beraktivitas sama sekali.

Sifat timbul-tenggelam tersebut memang kentara. 27 organisasi penghayat kepercayaan dari total 187 organisasi penghayat kepercayaan di Indonesia bukanlah jumlah yang sedikit. Tetapi sebenarnya sifat dinamis ini sangat wajar. Biasanya memang aliran kepercayaan ini sering tidak bertahan lama dari masa hidup pendiri penghayat kepercayaan tersebut (Lombard : 1996). Maka, biasanya memang organisasi penghayat kepercayaan yang disebut oleh Lombard sebagai perkumpulan kebatinan, hanya bertahan dan berlangsung selama dua generasi saja.
Artinya bahwa memang organisasi penghayat kepercayaan hanya berumur pendek. Efeknya adalah para penghayat kepercayaan menjadi tidak dilibatkan dan tidak dimasukkan di dalam kolom agama karena organisasi penghayat kepercayaan yang lemah. Jika berkaca pada tabel 1, bisa disimpulkan bahwa yang menjadi dasar pertama dan utama kelompok agama mayoritas sebagai kelompok kepentingan yang masuk dalam kolom agama yang diakui negara adalah karena jumlahnya yang begitu besar. Tetapi harus diingat pula bahwa karena posisi kelompok kepentingan tadi dipegaruhi jumlah, maka yang paling berpengaruh adalah umat beragama islam karena jumlahnya yang begitu besar. Maka kelompok islam akan menjadi kelompok kepentingan yang bisa memveto sebuah kebijakan, termasuk kebijakan penghapusan kolom agama yang saat ini sedang ramai dibicarakan semenjak putusan MK terkait kolom agama. Artinya, tindakan apapun yang dilakukan perwakilan kelompok islam akan mempengaruhi, bahkan mungkin bisa saja mengancam policy-action dari putusan tersebut karena posisi kelompok tersebut yang sangat kuat.

Yang mengherankan adalah bahwa agama Khong $\mathrm{Hu}$ Chu adalah penduduk yang paling sedikit, bahkan lebih sedikit daripada para penghayat kepercayaan, dari segi jumlah penganutnya di Indonesia, tetapi tetap disahkan menjadi agama resmi oleh negara. Agama Khong Hu Chu disahkan menjadi agama negara karena sejarah diskriminasi yang diterima oleh umat Khong Hu Chu yang didiskriminasi oleh pemerintahan pada masa orde baru. Nasib yang sama juga terjadi pada aliran penghayat kepercayaan yang 
mengalami diskriminasi (lihat tabel 4). Pertanyaan yang kemudian muncul adalah apa kriteria pemerintah untuk mengakui ada atau tidaknya suatu agama? Maka ada prasangka yang muncul bahwa pemerintah melakukan politik agama.

\section{Tabel 4}

Bentuk Diskriminasi Pemerintah Terhadap Penghayat Kepercayaan

\section{MASA BENTUK DISKRIMINASI}

Orde Lama Agama didefinisikan sebagai yang memiliki kitab suci, nabi, dan pengakuan

internasional. Definisi ini menjadi dasar untuk memilih siapa yang dilayani, siapa yang tidak dilayani.

1953 - Pemerintah Orde
Lama membentuk Pengawas Aliran Kepercayaan (Pakem).

- Pemerintah membentuk Badan Koordinasi Kebatinan Indonesia (BKKI) Lahir UU PNPS 1/1965 tentang Penodaan

Agama yang ingin melindungi agama dari penodaan oleh aliran kepercayaan.

- Setelah Gestok, penghayat kepercayaan mendapatkan tekanan besar,

\begin{tabular}{|c|c|}
\hline & $\begin{array}{lr}\text { dan dicurigai } \\
\text { sebagai bagian } \\
\text { dari komunisme. }\end{array}$ \\
\hline 1970 & $\begin{array}{l}\text { BKKI berubah bentuk } \\
\text { menjadi Badan Kongres } \\
\text { Kepercayaan Kejiwaan } \\
\text { Kerohanian Kebatinan } \\
\text { Indonesia (BK5I). }\end{array}$ \\
\hline 1973 & $\begin{array}{l}\text { Lahir TAP MPR tentang } \\
\text { GBHN yang } \\
\text { menyatakan bahwa } \\
\text { agama dan } \\
\text { kepercayaan adalah } \\
\text { ekspresi kepercayaan } \\
\text { terhadap Tuhan YME } \\
\text { yang sama-sama 'sah', } \\
\text { dan keduanya 'setara'. }\end{array}$ \\
\hline 1978 & $\begin{array}{l}\text { Lahir TAP MPR Nomor } \\
4 / 1978 \text { yang } \\
\text { menyatakan bahwa } \\
\text { kepercayaan bukanlah } \\
\text { agama, melainkan } \\
\text { kebudayaan. TAP ini } \\
\text { juga mengharuskan } \\
\text { adanya kolom agama } \\
\text { (yang wajib diisi } \\
\text { dengan satu di antara } 5 \\
\text { agama) dalam formulir } \\
\text { pencatatan sipil. }\end{array}$ \\
\hline 2006 & $\begin{array}{l}\text { UU Administrasi } \\
\text { Kependudukan direvisi, } \\
\text { tetapi tetap } \\
\text { mendiskriminasikan } \\
\text { penghayat } \\
\text { kepercayaan, yaitu } \\
\text { dengan adanya Pasal } \\
61 \text { UU Adminduk 2006: } \\
\text { identitas kepercayaan } \\
\text { tidak dicatatkan dalam } \\
\text { kolom agama. }\end{array}$ \\
\hline
\end{tabular}


Studies Graduate School, Universitas Gadjah Mada ${ }^{5}$

Maka karena itulah, urusan kolom agama pada administrasi kependudukan sangat besar dampaknya bagi masyarakat penganut agama selain keenam agama utama di Indonesia, terutama para penghayat kepercayaan. Dampaknya adalah ada hak lain yang tidak terpenuhi, seperti pembinaan dan pembelajaran mengenai agamanya (misalnya di sekolah). Dan ini akan berefek domino pula pada hak-hak lain seperti dana bantuan pendidikan keagamaan yang biasanya diberikan pemerintah, juga fasilitas-fasilitas keagamaan yang bisa dipastikan tidak menyentuh para penghayat kepercayaan. Untuk tingkat individual penghayat kepercayaan, maka hak-hak negara akan sulit didapatkan. Hak seperti kesehatan, pendidikan, keselamatan, dan lain-lain akan sulit untuk diakses. Bahkan terkadang seorang penghayat kepercayaan bisa berurusan dengan hukum karena dianggap tidak memiliki identitas yang jelas karena tidak memiliki identitas bagi umat yang konsisten untuk tidak memilih agama besar (sebelum muncul UU 23 Tahun 2006).

Bahkan walaupun muncul UU 23 Tahun 2006 yang berisi tentang anggapan solusi jitu dari negara tentang pemberian tanda "-", malah menimbulkan pertanyaan-pertanyaan baru bagi para penghayat kepercayaan. Maka akan timbul pertanyaanpertanyaan dari masyarakat non penghayat kepercayaan, kemudian juga efeknya bisa mempersulit proses pemakaman seseorang penghayat kepercayaan, sampai pada cap atheis yang melekat pada para penghayat kepercayaan (Mulia : 2018).

$$
\text { Yang menjadi problem }
$$

selanjutnya menurut Benz dan Papadopoulos adalah bahwa Beberapa aktor yang mengambil bagian dalam policy networks tidak selalu pemegang mandat rakyat, mereka tidak dibatasi oleh janji pemilu, dan mereka tidak harus mengantisipasi sanksi pemilu. Ketika mereka memiliki pertimbanganpertimbangan ini, misalnya sebagai perwakilan kelompok kepentingan, maka mereka bertanggung jawab kepada kepentingan sektoral dan tidak untuk banyak kepentingan. Maka susah untuk mengawasi para kelompok kepentingan yang terlibat di dalam proses governance.

Maka ketika di dalam governance seorang yang mewakili kelompok kepentingan umat beragama tertentu, karena berbicara agama berarti berbicara tentang keyakinan dan interpretasi agama, membuat para konstituen biasanya menjadi satu suara karena kesamaan iman dan kepercayaan tersebut. Maka pengawasan yang dilakukan juga tidak maksimal. Ini membuat kelompokkelompok lain yang tidak bisa masuk ke dalam proses governance seperti kelompok penghayat kepercayaan sulit untuk masuk ke dalam proses governance.

Menurut Peter Berger semua dunia yang dibangun secara sosial adalah rawan, karena keberadaannya terancam oleh kepentingan diri manusia atau kebodohan manusia. Karena itu, diperlukan legitimasi untuk pemeliharaan dunia. Banyak legitimasi yang ada untuk pemeliharaandunia.

\footnotetext{
5 https://crcs.ugm.ac.id/news/10803/menguji-uuadminduk-diskriminasi-dalam-pengosongankolom-agama.html\#
} 
Namun, agama, secara historis, merupakan instrumentalis legitimasi yang paling tersebar dan efektif. Semua legitimasi mempertahankan realitas yang didefinisikan secara sosial. Agama melegitimasikan sedemikian efektifnya, karena agama menghubungkan konstruksi-konstruksi realitas rawan dari masyarakat-masyarakat empiris dengan realitas purna (Manuaba : 2008). Maka ketika timbul konflik di dalam dunia sosial, berarti terjadi pergeseran prioritas dari lembaga karena ada faktor kepentingankepentingan individu. Dalam hal ini tentulah aktor-aktor yang ada di dalam pemerintahan.

\section{Kolom Agama dan Ketahanan Nasional}

Berdasarkan framework problem governance dari Benz dan Papadopoulos yang menyebutkan bahwa governance mungkin juga lebih baik terhadap 'ketahanan', dan menghasilkan lebih banyak keputusan 'terkait masa depan', karena para pembuat keputusan tidak dibatasi oleh perhitungan jangka pendek persaingan pemilu, maka seharusnya pemerintah sadar bahwa adanya kolom agama ini memang menimbulkan sebuah diskriminasi, dimana berpotensi memicu konflik, karena diskriminasi membatasi hak-hak seseorang/orang lain dan merupakan ungkapan ketidakadilan.

Ada beberapa faktor yang menyebabkan diskriminasi, yaitu:
a. Kegagalan
proses asimilasi;
b. Adanya pluralisme budaya dan agama;
c. Klasifikasi sosial buatan dan warisan kolonial;
d. Dampak dari kebijakan rezim yang sedang berkuasa;
e. Adanya kecemburuan sosial antar ras / antar etnis; dan
f. Paham nativisme yang berlebihan.
(Liliweri : 2005)

Lebih lanjut, diskriminasi memiliki 3 tipe (Basherina : 2008), yaitu:

a. Aturan yang diskriminatif;

b. Perasaan didiskriminasi; dan

c. Pelaksanaan yang diskriminatif.

Pemerintah Republik Indonesia juga sudah mengatur apa sebenarnya definisi dari diskriminasi. Definisi dari diskriminasi tersebut tercantum dalam Undang-Undang Nomor 39 Tahun 1999 Tentang Hak Asasi Manusia pasal 1 ayat 3 yang menyebutkan bahwa diskriminasi adalah "setiap pembatasan, pelecehan, atau pengucilan yang langsung ataupun tak langsung didasarkan pada pembedaan manusia atas dasar agama, suku, ras, etnik, kelompok, golongan, status sosial, status ekonomi, jenis kelamin, bahasa, keyakinan politik, yang berakibat pengurangan, penyimpangan atau penghapusan pengakuan, pelaksanaan atau penggunaan hak asasi manusia dan kebebasan dasar dalam kehidupan baik individual maupun kolektif dalam bidang politik, ekonomi, hukum, sosial, budaya, dan aspek kehidupan lainnya."

Berkaitan dengan kolom agama pada administrasi kependudukan, ada dua bentuk diskriminasi yang dilakukan oleh pemerintah terhadap para penghayat kepercayaan. Yang pertama adalah adanya diskriminasi terhadap kolom agama itu sendiri. Dengan 
ditulisnya agama seseorang di administrasi kependudukan, membuat seorang warga negara menjadi mengalami perbedaan diskriminatif ketika para penghayat kepercayaan tidak dimasukkan agama/kepercayaannya ke dalam administrasi kependudukan karena database pilihan agama pada administrasi kependudukan tidak tersedia. Maka akan muncul peluang tidak terpenuhinya hak-hak para penghayat kepercayaan, yang otomatis akan menghapus prinsip kesetaraan seseorang di depan negara. Ketidak adilan tersebut ditunjukkan dengan fasilitas yang diberikan negara pada kelompok agama yang diakui negara (misalnya hari libur nasional atau bantuan dana keagamaan) yang mana hal itu pasti tidak akan bisa dinikmati oleh para penghayat kepercayaan.

Diskriminasi yang kedua adalah turunan dari diskriminasi yang pertama, di mana ketika negara mengakui dan mengistimewakan 6 agama saja, membuat seorang penganut agama yang diakui tersebut menjadi merasa superior. Superioritas tersebut diperkuat dengan tidak adanya isi kolom agama bagi para pemeluk kepercayaan yang masih belum diakui. Sudah banyak berita tentang penganut agama yang ekstrimis radikal yang cenderung memusuhi orang yang berbeda dengan apa yang dia yakini. Belum lagi pemerintah yang sering sekali kalah dengan para penganut agama besar yang diakui negara yang biasanya melakukan sweeping sepihak terhadap penganut kepercayaan ataupun orang yang berbeda dengan mereka.

pada $\begin{gathered}\text { Dengan adanya kolom agama } \\ \text { dokumen }\end{gathered}$
kependudukan, sebenarnya pemerintah telah membuka celah terjadinya diskriminasi terhadap para warga negara yang kepercayaannya belum diakui oleh negara. Pola diskriminasi yang terjadi adalah ketika negara menolak mencantumkan agama seorang warga negara pada kolom agama di KTP atau KK karena agama/kepercayaannya belum diakui negara, dan malah ditulis lain-lain atau tanda "-". Maka penghapusan kolom agama di dalam administrasi kependudukan merupakan hal yang harus dilakukan pemerintah jika pemerintah memang berkomitmen untuk melakukan governance di Indonesia yang bermasyarakat majemuk, dan sekaligus untuk menegakkan UUD 1945 Pasal 29 Ayat 2 yang menjamin kepada seluruh warga negara Indonesia untuk memilih agama yang dia yakini.

Sekali lagi, dengan adanya pencantuman kolom agama pada pada dokumen administrasi kependudukan, menunjukkan bahwa negara bersikap arogan dan tidak menghormati kepentingan-kepentingan dari para penghayat kepercayaan untuk diakui kepercayaannya oleh negara. Bahkan PBB pernah mengeluarkan rekomendasi sebagai berikut:

"The Committee recommends that the State party treat equally all religions and beliefs and ensure the enjoyment of freedom of thought, conscience and religion for ethnic minorities and indigenous peoples. Noting that the State party is considering removing the mention of religion on identification cards in order to be in line with the objectives of the Convention, the Committee strongly recommends it to do so in a timely manner, and to extend such a policy to all legal documents. The Committee also recommends the adoption of 
legislation allowing individuals to contract a civil marriage if they so wish." (International Convention On the Elimination Of all Forms of Racial Discrimination CERD/C/IDN/CO/3, 15 Agustus $2007^{6}$ )

Dan juga perlu diingat bahwa ketika pemerintah mengakui setiap agama dan tetap memasang kolom agama pada dokumen administrasi kependudukan, maka justru akan merepotkan pemerintah sendiri karena akan berpotensi menyuburkan pahampaham baru yang bisa saja paham tersebut bertentangan dengan Pancasila dan UUD 1945, dan menimbulkan ancaman bagi keamanan nasional.

Agama sebagai identitas, selalu menjadi pedang bermata dua. Memang di satu sisi, agama memiliki manfaat sebagai pencatatan pernikahan. Tetapi di sisi lain, peletakan kolom agama sebagai identitas di dalam dokumen kependudukan seperti KTP dan/atau KK justru menjadi hal yang riska untuk diungkapkan ke khalayak ramai. Seperti ketika terjadi kasus sweeping pada saat situasi memanas antar pemeluk agama,

\footnotetext{
6 Pernyataan yang menjadi dasar PBB mengeluarkan rekomendasi di atas adalah sebagai berikut: "While noting the statement made by the delegation that there are no "recognized" or "non-recognized" religions in Indonesia, the Committee expresses concern at the distinction made between Islam, Protestantism, Catholicism, Hinduism, Buddhism and Confucianism, which are often referred to in legislation, and other religions and beliefs. The Committee is concerned at the adverse impact of such a distinction on the rights to freedom of thought, conscience and religion of persons belonging to ethnic groups and indigenous peoples. It notes with particular concern that under Law No. 23 of 2006 on Civic Administration, individuals are required to mention their faith on
}

seperti kasus Poso, Ambon, sampai kasus aliran kepercayaan di Aceh Singkil.

Jika dikaitkan lagi dengan Undang-Undang Otonomi Khusus yang berlaku di Nanggroe Aceh Darussalam (NAD) dan Papua, maka penghapusan kolom agama pada dokumen kependudukan akan turut mendukung promosi keamanan dan perlindungan bagi warga negara di wilayah tersebut, dan juga mendukung local wisdom untuk berkembang di daerah-daerah tersebut.

Selama ini kita tahu bahwa Qanun di NAD masih kontroversi karena ada muatan yang bersifat diskriminatif, terutama untuk kaum perempuan dan juga warga non-muslim karena pasalpasalnya yang masih karet dan belum kuatnya institusi pengawasan para eksekutor Qanun.7

NAD dan Papua memiliki anggaran dana otonomi khusus yang lebih besar daripada provinsi lain di Indonesia dengan tujuan kemajuan perekonomian dan kualitas hidup masyarakatnya. Tetapi rupanya marjinalisasi masih terus terjadi di kawasan tersebut. Perlindungan kepada para kelompok minoritas tidak sampai menyentuh kepada pemberian

\footnotetext{
legal documents such as identity cards and birth certificates, and that those wishing either to leave the column blank or to register under one of the "non-recognized" religions reportedly face discrimination and harassment. The Committee also notes with concern that men and women of different religions face great difficulties in officially registering their marriages, and that their children are not provided with birth certificates, as acknowledged by the State party (arts. 2 and 5)"

http://www.bbc.com/indonesia/berita_indonesi a/2016/04/160414_indonesia_aceh_qanun_haki $\mathrm{m}$ dan http://www.dw.com/id/qanun-jinayahaceh-rugikan-perempuan/a-41074165
} 
rasa aman bagi kaum minoritas dengan jaminan keamanan dan ketenangan dalam menjalani hidupnya sehari-hari. Hal ini karena masih diberlakukannya pertahanan teritorial oleh TNI, dengan pendekatan sekuritisasi sekaligus meningkatkan jumlah personil dari pasukan TNI, yang juga ditambah dengan personil Polri. Ditambah pula dengan adanya potensi banyak pelanggaran HAM yang terjadi di Papua. Bisa dilihat dari jumlah wartawan yang sangat dibatasi masuk ke papua dan juga wartawan asli papua yang lebih sering mendapat diskriminasi dari aparat keamanan, daripada wartawan yang berasal dari pulau Jawa. ${ }^{8}$ Ini juga ditambah dengan fakta bahwa selalu ada pengawasan intensif dan pengamanan yang berlebihan di sekitar Provinsi Papua.

Maka ketika kolom agama dihapuskan, mendorong juga untuk mendapatkan jaminan keamanan akan yang didasarkan pada Otonomi Khusus, yang juga berdasar pada keunikan budaya, bukan pada agama. Maka, pemerintah memiliki kontribusi untuk membangun kedua Provinsi tersebut dengan lebih baik dengan mengurangi aksi-aksi sweeping yang berujung pada diskriminasi agama terhadap minoritas, yang biasanya dilakukan dengan pemeriksaan KTP pada lokasi-lokasi tertentu. Imbasnya adalah penghapusan kolom agama tersebut akan sangat bermanfaat bagi para aliran kepercayaan dan juga agamaagama lain selain Muslim di Aceh, ataupun bagi para muslim dan agamaagama lain selain Kristen di Papua.

\section{KONKLUSI}

Ketika agama masuk ke dalam ruang publik, pasti akan selalu timbul kontroversi. Interpretasi agama yang beragam tentang kebenaran agama yang pasti dipercaya oleh masingmasing, membuat timbulnya dua pertentangan. Yaitu yang pertama menganggap bahwa masuknya agama ke dalam ruang publik akan memfokuskan pada peran agama terhadap mentalitas seseorang di dalam ruang publik. Sebaliknya, ada juga yang menghendaki bahwa agama adalah wilayah privat. Fakta yang terjadi saat ini adalah politisasi bahasabahasa agama untuk kepentingan politik jangka pendek menjadi lebih dominan untuk dilakukan, daripada logika berpikir yang tulus tentang fungsi adanya agama di ruang publik. Akibatnya, kehadiran agama di dalam ruang publik justru banyak menimbulkan ketegangan, konflik, dan diskriminasi yang berujung pada konflik horizontal akibat dari konflik kepentingan, yang mana yang sering menjadi korban biasanya kaum minoritas. Kondisi ini jelas sangat kontraproduktif dengan cita-cita kehidupan publik yang berdiri di atas pondasi Good Governance.

Selayaknya agama tidak menjadi pusat kehidupan bernegara yang berbasi kepada kebangsaan religius seperti Indonesia. Karena interpretasi agama yang berbeda, tentu di dalam kehidupan bernegara pun satu agama mayoritas tidak mungkin mampu memenuhi pemikiran agama dan penghayat kepercayaan yang bermacam-macam. Agama harus mampu untuk mengendalikan diri agar agama tidak terjebak pada simbolisasi

\footnotetext{
${ }^{8}$ https://tirto.id/hari-kebebasan-pers-dunia-tanpapapua-cn6B
} 
agama dan politisasi agama yang akan membahayakan kehidupan publik, berbangsa, dan bernegara. Dengan dihapusnya kolom agama dan memasukkan agama ke dalam ranah privat akan membuat negara ikut mencegah ancaman-ancaman disintegrasi bangsa yang pasti tidak akan diinginkan. Dan agama harus mampu berhubungan dengan publik untuk mendukung good governance, agar Indonesia menjadi lebih baik lagi.

\section{DAFTAR PUSTAKA}

Basherina, Almanda. (2008). Tesis Kebijakan Formulasi Tindak Pidana Diskriminasi Ras Dan Etnis Dalam Perspektif Pembaharuan Hukum Pidana. Semarang. Universitas Diponegoro.

Benz, Arthur and Yannis Papadopoulos. (2006). Governance and Democracy: Comparing National, European and International Experiences. Routledge. New York.

Liliweri, Alo. (2005). Prasangka \& Konflik; Komunikasi Lintas Budaya Masyarakat Multikultur. LkiS. Yogyakarta.

Lombard, Denys. (1996). Nusa Jawa: Silang Budaya Bagian 3, Warisan Kerajaan Konsentris (terj.). Gramedia Pustaka Utama. Jakarta.

Manuaba, IB Putra. Memahami Teori Konstruksi Sosial. Jurnal Masyarakat Kebudayaan dan Politik Universitas Airlangga Vol. 21 No. 3 Edisi 8 Juli 2008.

Miall, Hugh. (2000). Resolusi Damai Konflik Kontemporer, Menyelesaikan, Mencegah, Mengelola, dan Mengubah Konflik Bersumber Politik, Sosial, Agama, dan Ras (terj.). Grafindo Persada. Jakarta.
Mulia, Siti Musdah. (2018). Dehumanisme Politik Agama di Indonesia. Artikel http://www.mujahidahmuslimah. com/home/dok/dehumanismepolitik-agama-di-Indonesia.pdf

Pelly, Usman. (2000). Dialog Budaya Spiritual. Direktorat Jenderal Kebudayaan Departemen Pendidikan Nasional. Jakarta.

Peraturan Pemerintah Nomor 37 Tahun 2007 Tentang Pelaksanaan Undang-Undang Nomor 23 Tahun 2006 Tentang Administrasi Kependudukan.

Sedarmayanti. (2007). Good Governance dan Good Corporate Governance. Mandar Maju. Kota Bandung.

Undang-Undang Dasar Negara Kesatuan Republik Indonesia Tahun 1945.

Undang-Undang Nomor 23 Tahun 2006 Tentang Administrasi Kependudukan.

Undang-Undang Nomor 24 Tahun 2013 Tentang Perubahan Atas UndangUndang Nomor 23 Tahun 2006 Tentang Administrasi Kependudukan.

Undang-Undang Nomor 39 Tahun 1999 Tentang Hak Asasi Manusia.

United Nations International Convention On the Elimination Of all Forms of Racial Discrimination. Consideration Of Reports Submitted by States Parties Under Article 9 of The Convention. CERD/C/IDN/CO/3. 15 Agustus 2007. 